\title{
Screening of beneficial bacteria associated with Calophyllum brasiliense Cambess so as to develop microbial inoculants for agriculture
}

\author{
Bruno Rogério de Souza ${ }^{1 *}$, Lílian Estrela Borges Baldotto ${ }^{2}$, Alessandra Monteiro de Paula ${ }^{3}$, Fabrício Souza \\ Campos $^{4}$, Klever Cristiano Silveira ${ }^{2}$, Pabline Marinho Vieira ${ }^{5}$, Fernando Fabriz Sodré ${ }^{\text {, Jader Galba Busato }}{ }^{3}$ \\ ${ }^{1}$ University of Brasília, Institute of Chemistry, Darcy Ribeiro University Campus, PO Box 4478, CEP 70910-970, Brasília / \\ DF, Brazil \\ ${ }^{2}$ Federal University of Viçosa, Forest Campus, Rodovia LMG 818, Km 6, CEP 35690-000, Florestal / MG, Brazil \\ ${ }^{3}$ University of Brasília, Faculty of Agronomy and Veterinary Medicine, Darcy Ribeiro University Campus, PO Box 4508, \\ CEP 70910-970, Brasília / DF, Brazil \\ ${ }^{4}$ Federal University of Tocantins, University Campus of Gurupi, PO Box 66, CEP 77402-970, Gurupi / TO, Brazil \\ ${ }^{5}$ Institute Federal Goiano, Department of Biological Sciences, highway Geraldo Silva Nascimento Km-12.5 - Rural Area, \\ CEP 75790-000, Urutaí / GO, Brazil
}

*Corresponding author: brsvzp@hotmail.com

\begin{abstract}
Beneficial bacteria belong to a group of microorganisms that are able to enhance plant growth by several mechanisms. In this study, phosphorus and zinc solubilizing, nitrogen-fixing and indole acetic acid (IAA) producing bacteria associated with $C$. brasiliensis were screened to develop microbial inoculants (MI) for use in agriculture. Characterization and identification of screened bacteria were also performed. A total of thirty-one nitrogen-fixing bacteria isolates were obtained, of which 28 showed the ability to solubilize phosphorus and 25 to solubilize zinc. The isolate AP-JNFb-3-2, belonging to the genus Pseudomonas, presented the highest value of solubilized phosphorus $\left(100.4 \mu \mathrm{g} \mathrm{mL}{ }^{-1}\right)$. The isolates AP-JNFb-3-2 and RHI-JMVL-3-1, associated with the genera Pseudomonas and Enterobacter, respectively, showed the highest values for zinc solubilization $\left(147.8\right.$ and $\left.147.7 \mu \mathrm{g} \mathrm{mL}^{-1}\right)$. Isolate RO-LGI.P-3-2, belonging to the genus Pseudomonas, was the most promising for IAA production $\left(0.52 \mu \mathrm{g} \mathrm{mL}^{-1}\right)$. The results obtained showed the presence of a large diversity of beneficial bacteria associated with $C$. brasiliensis, which may be explored as $\mathrm{MI}$ in agriculture.
\end{abstract}

Keywords: plant growth; microbial inoculum; 16S rRNA gene sequencing; phosphorus solubilization; zinc solubilization; indole acetic acid production.

Abbreviations: C. brasiliensis_Callophyllum brasiliensis Cambess (guanandi); JMV_specific media with mannitol, JMVL_specific media with change in $\mathrm{PH}, \mathrm{NFb}$ _specific media with malic acid, JNFb_specific media with yeast extract, LGI_specific media crystal with sugar; LGI.P_specific media with acetic acid; DYGS_generalized specific media; RO_Root; AP_aerial part ; RHI_rhizosphere ; IAA_indole acetic acid; ANOVA_analysis of molecular variance; MPN _most probable number.

\section{Introduction}

Global trends in productive agrosystems are moving towards the use of sustainable agricultural amendments. Plant biostimulants meet this requirement and are defined as substances or microorganisms applied to plants in low quantities with the aim of enhancing nutrition efficiency, abiotic stress tolerance and crop quality traits (Du Jardin, 2015). Particularly in Brazilian agriculture, the success experienced with atmospheric nitrogen-fixing microorganisms in recent decades has encouraged the development and use of MI. Besides nitrogen fixation, MI may promote plant growth by increasing the production of organic acids and chelating substances, resulting in higher solubility of poor soil-soluble phosphorus and zinc (Chen YO et al., 2006; Gontia-Mishra et al., 2017). They also produce growth regulators such as auxins, cytokinins and gibberellins (Groppa et al., 2012) which can modulate root development and increase water and nutrient absorption by plants, as well as enhance disease control due to production of antibiotics or cell wall lytic enzymes (Sarma et al., 2015). Additionally, these regulators can reduce environmental stress resulting from drought, extreme heat or salinity (Groppa et al., 2012).

Many bacteria genera have been evaluated as $\mathrm{MI}$, showing significant increases in plant-growth and yields. However, most 
of these studies have been screened and performed on annual crops (Groppa et al., 2012; Sarma et al., 2015; Gontia-Mishra et al., 2017), and there is a lack of knowledge with respect to long cycle plants. $C$. brasiliensis is a woody plant that has been gaining prominence due its economic importance for farmers, vigorous growth ability in degraded areas and its potential for the implantation of agroforestry systems. The Brazilian savanna is one of the regions with native occurrence of $C$. brasiliensis and despite its extensive agricultural development targeting production of grains, there is a growing interest in sustainable wood exploitation in this region. However, soils of the Brazilian savanna are weathered oxisols (65\%) and ultisols $(15 \%)$, presenting deficiency in soluble forms of nutrients such as phosphorus and zinc (Rada, 2013; Lopes and Guilherme, 2016). Furthermore, the region presents a long dry season comprising 5-6 months, the occurrence of dry spells during the rainy season, low available water-retention capacity and limited root development as a function of aluminum toxicity (Lopes and Guilherme, 2016).

In this way, it is expected that an efficient microbial assemblage assists $C$. brasiliensis when submitted to the adverse conditions of poor soils in the Brazilian savanna. However, to our knowledge this attempt has not yet been explored. The present study was carried out to screen phosphorus and zinc solubilizing, nitrogen-fixing and indole acetic acid (IAA) producing bacteria associated with $C$. brasiliensis in an attempt to develop MI with potential for use in agriculture.

Results

\section{Nitrogen-fixing bacteria that were isolated and quantified}

Nitrogen-fixing bacteria populations from the rhizosphere, roots and aerial parts of $C$. brasiliensis, evaluated by the MPN method, are presented in Fig. 1 . The six growth media showed no differences with regards to the bacteria population present in the roots (Fig. 1A). A similar result was observed for bacteria from the rhizosphere (Fig. 1C). On the other hand in the aerial part the JMV, LGI.P and JNFb media presented the highest bacteria growth compared to the LGI medium (Fig. 1B). The $\mathrm{NFb}$ and JMVL media presented intermediate growth, with no statistical difference from the others. In general, the results of the MPN for the roots illustrated accentuated proliferation of the bacteria in the six specific media (average of 5.26 log cell number $\mathrm{g}^{-1}$ ) when compared with the aerial part (3.93 log cell number $\left.\mathrm{g}^{-1}\right)$ and rhizosphere (3.54 log cell number $\mathrm{g}^{-1}$ ). The presence of a high number of opportunistic microorganisms results in high competition in the rhizosphere and it may be recognized as an important mechanism for population regulation. Thus, bacteria and other microbial groups may compete for nutrients and compounds exuded by the roots, reducing the nitrogen-fixing bacteria population.

A total of thirty-one bacterial isolates were obtained, out of which 11 were from the rhizosphere, 13 from the roots and 7 from the aerial part of $C$. brasiliensis. Isolates from the semisolid media (JNFb, NFb, LGI, LGI-P, JMV and JMVL) allowed for obtaining nitrogen-fixing bacteria detected by the formation of an aerotactic film, which were then purified on selective solid media.

\section{Identification of morphological and gram stain evaluation of} the isolated bacteria

Morphological characteristics of the isolates grown on the specific media are presented in Table 1. There was predominance of white center staining ( 25 isolates, $81 \%$ of the total) and lens type elevation ( 28 isolates, $90 \%$ ). All isolates presented colonies with smooth surfaces. Mucus was observed in 4 isolates (13\%), and 10 isolates (32\%) presented a colony size less than $1 \mathrm{~mm}$. Except for the isolates RO-NFb-3-2, ROJNFb-4-2, RO-LGI-4-1 and RO-LGI.P-3-2, all others were gram negative.

\section{Identification of 16S rRNA and phylogenetic analysis bacteria isolated from plant species}

Phylogenetic analysis of the 16S rDNA gene sequencing was performed in the 31 isolates. The NCBI database was used to identify and compare the sequences. Twelve isolates (RHILGI.P-3-1, RHI-JMVL-3-1, RO-JMVL-4-1, AP-JMVL-3-1, RHI-NFb3-4, AP-JNFb-3-1, RO-JNFb-4-2, RO-NFb-3-4, AP-JNFb-3-2, RONFb-3-2, RO- LGI.P-3-2 and RHI-NFb-3-3) were used to obtain a phylogenetic tree showing the relationship of isolates from related bacteria, based on partial sequencing of the $16 \mathrm{~S}$ rRNA (Fig. 2). PCR products from 19 isolates did not present patterns to produce high quality sequence data, even after conducting the purification methods.

The phylogenetic analysis revealed that the isolates belonged to four genera: Enterobacter, Escherichia, Pseudomonas and Bacillus. Nine isolates (AP-JMVL-3-1, RHI-NFb-3-4, AP-JNFb-3-1, RO-JNFb-4-2, RO-NFb-3-4, AP-JNFb-3-2, RO-NFb-3-2, RO- LGI.P3-2 and RHI-NFb-3-3) showed $99 \%$ or more similarity between available GenBank sequences. On other hand, isolates RHILGI.P-3-1, RHI-JMVL-3-1 and RO-JMVL-4-1 showed the lowest similarity (87\%).

Based on the sequences of the isolates RHI- LGI.P-3-1, RHIJMVL-3-1, RO-JMVL-4-1 and AP-JMVL-3-1, Blast search results showed that they are closely related with different strains of the genus Enterobacter. Isolates AP-JNFb-3-2, RO-NFb-3-2 and RO- LGI.P-3-2 were closely related (99\%) to species of the genus Pseudomonas. The isolates RO-LGI.P-3-2, AP-JNFb-3-2 and $\mathrm{RHI}-\mathrm{NFb}-3-2$ were related to the genus Pseudomonas, with $100 \%$ occurrence. In the isolate RHI-NFb-3-3 there was $100 \%$ occurrence for the genus Bacillus. Four isolates (RHI-NFb-3-4, AP-JNFb-3-1, RO-JNFb-4-2, RO-NFb-3-4) were closely related $(100 \%)$ to the Escherichia coli specie.

Qualitative and quantitative measurement of solubilization by phosphorus and zinc bacteria

Twenty-eight isolates (90\%) presented the ability to solubilize phosphorus in vitro, showing a characteristic halo around the colonies. Only 3 isolates (RHI-JMV-3-1, RO-NFb-3-4 and RHINFb-3-3) did not exhibit this potential. Variable halo diameters were observed, where the isolates AP-JMV-2-1, AP-JMVL-3-1, 
Table 1. Morphological characteristics of the isolates grown in specific growth media.

\begin{tabular}{|c|c|c|c|c|c|c|c|c|c|}
\hline Isolate code $e^{(1)}$ & Color & Size & Elevation & Margin & Surface & Mucus & $\begin{array}{l}\text { Gram } \\
\text { nature }\end{array}$ & $\begin{array}{l}\text { Halo } \\
\text { diameter } \\
\text { for } P(\mathrm{~mm})\end{array}$ & $\begin{array}{l}\text { Halo } \\
\text { diameter } \\
\text { for } \\
\mathrm{Zn}(\mathrm{mm})\end{array}$ \\
\hline AP-JMV-2-1 & Milky aspect yellow center & $>1 \mathrm{~mm}$ & Lens & Lobed & Smooth & - & - & 17 & 17 \\
\hline RO-JMV-4-1 & Clear white center & $<1 \mathrm{~mm}$ & Plana & Entire & Smooth & + & - & 13 & 13 \\
\hline RHI-JMV-3-1 & Translucent edge, clear white center & $>1 \mathrm{~mm}$ & Plana & Entire & Smooth & - & - & - & - \\
\hline AP-JMVL-3-1 & Translucent edge, clear white center & $>1 \mathrm{~mm}$ & Lens & Entire & Smooth & - & - & 18 & 18 \\
\hline RO-JMVL-4-1 & Translucent edge, clear white center & $1 \mathrm{~mm}$ & Lens & Entire & Smooth & - & - & 16 & 3 \\
\hline RHI-JMVL-3-1 & Translucent edge, clear white center & $>1 \mathrm{~mm}$ & Lens & Entire & Smooth & - & - & 14 & 5 \\
\hline AP-NFb-2-1 & Milky aspect white center & $<1 \mathrm{~mm}$ & Lens & Corrugated & Smooth & - & - & 15 & 6 \\
\hline RO-NFb-3-1 & Milky aspect white center & $>1 \mathrm{~mm}$ & Lens & Corrugated & Smooth & - & - & 15 & 8 \\
\hline RO-NFb-3-2 & Milky aspect white center & $1 \mathrm{~mm}$ & Lens & Corrugated & Smooth & - & + & 15 & 4 \\
\hline RO-NFb-3-3 & Milky aspect white center & $1 \mathrm{~mm}$ & Lens & Corrugated & Smooth & - & - & 14 & 6 \\
\hline RO-NFb-3-4 & Translucent edge, light white center & $<1 \mathrm{~mm}$ & Lens & Entire & Smooth & + & - & - & - \\
\hline RHI-NFb-3-1 & Milky aspect white center & $<1 \mathrm{~mm}$ & Lens & Corrugated & Smooth & - & - & 14 & 3 \\
\hline RHI-NFb-3-2 & Milky aspect white center, translucent edge & $<1 \mathrm{~mm}$ & Lens & Corrugated & Smooth & + & - & 14 & 5 \\
\hline RHI-NFb-3-3 & Milky aspect white center, transparent edge & $<1 \mathrm{~mm}$ & Lens & Corrugated & Smooth & + & - & - & - \\
\hline RHI-NFb-3-4 & Milky aspect white center & $<1 \mathrm{~mm}$ & Lens & Corrugated & Smooth & - & - & 14 & 8 \\
\hline APJNFb-3-1 & Yellow center, milky aspect white edge & $>1 \mathrm{~mm}$ & Lens & Entire & Smooth & - & - & 15 & 5 \\
\hline AP-JNFb-3-2 & Clear white center, clear edge & $1 \mathrm{~mm}$ & Lens & Entire & Smooth & - & - & 15 & - \\
\hline RO-JNFb-4-1 & Yellow center milky aspect, clear edge & $>1 \mathrm{~mm}$ & Lens & Entire & Smooth & - & - & 16 & 14 \\
\hline RO-JNFb-4-2 & Clear white center, clear edge & $>1 \mathrm{~mm}$ & Lens & Lobada & Smooth & - & + & 9 & - \\
\hline RO-JNFb-4-3 & Milky aspect white center, clear edge & $>1 \mathrm{~mm}$ & Lens & Entire & Smooth & - & - & 15 & 16 \\
\hline RHI-JNFb-3-1 & Milky aspect white center, clear edge & $>1 \mathrm{~mm}$ & Lens & Entire & Smooth & - & - & 18 & 17 \\
\hline RHI-JNFb-3-2 & Milky aspect white center, clear edge & $>1 \mathrm{~mm}$ & Convex & Entire & Smooth & - & - & 16 & 8 \\
\hline RHI-LGI-2-1 & White center & $<1 \mathrm{~mm}$ & Lens & Entire & Smooth & - & - & 14 & - \\
\hline RO-LGI-4-1 & White center, Translucent edge & $<1 \mathrm{~mm}$ & Lens & Entire & Smooth & - & + & 18 & 13 \\
\hline RO-LGI-4-2 & White center, clear edge white & $<1 \mathrm{~mm}$ & Lens & Corrugated & Smooth & - & - & 8 & 7 \\
\hline AP-LGI.P-2-1 & White center, clear edge white & $1 \mathrm{~mm}$ & Lens & Entire & Smooth & - & - & 11 & 3 \\
\hline AP-LGI.P-2-2 & White center & $1 \mathrm{~mm}$ & Lens & Entire & Smooth & - & - & 9 & 5 \\
\hline RHI-LGI.P-3-1 & Translucent & $1 \mathrm{~mm}$ & Lens & Corrugated & Smooth & - & - & 15 & 6 \\
\hline RHI-LGI.P-3-2 & Translucent & $1 \mathrm{~mm}$ & Lens & Corrugated & Smooth & - & - & 14 & 13 \\
\hline RO-LGI.P-3-1 & Translucent edge, light white center & $<1 \mathrm{~mm}$ & Lens & Entire & Smooth & - & - & 12 & 8 \\
\hline RO-LGI.P-3-2 & Translucent edge, light white center & $1 \mathrm{~mm}$ & Lens & Corrugated & Smooth & - & + & 11 & 9 \\
\hline
\end{tabular}
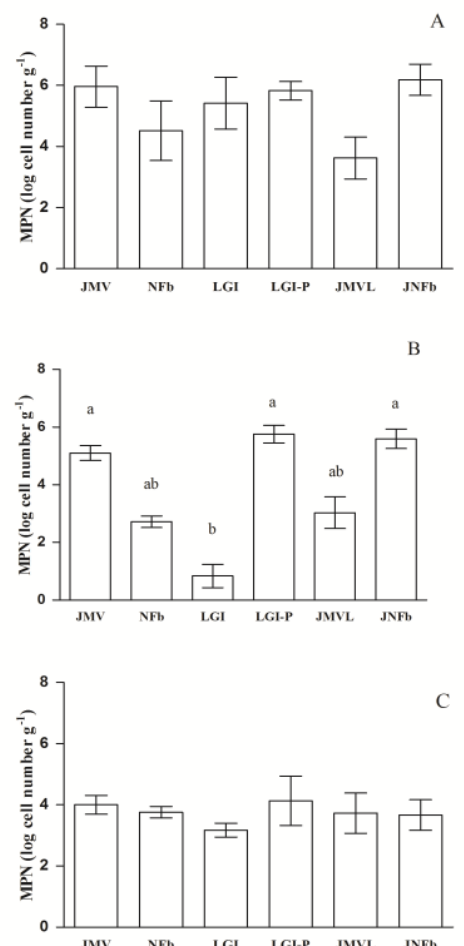

Fig 1. Log of the cell number of bacteria per gram present in (A) roots, (B) aerial part and (C) rhizosphere after growth on different cultivation media. Bars refer to standard deviations. Letters refer to the Tukey test $(p \leq 0.05)$. The absence of letters indicates lack of statistical difference. 


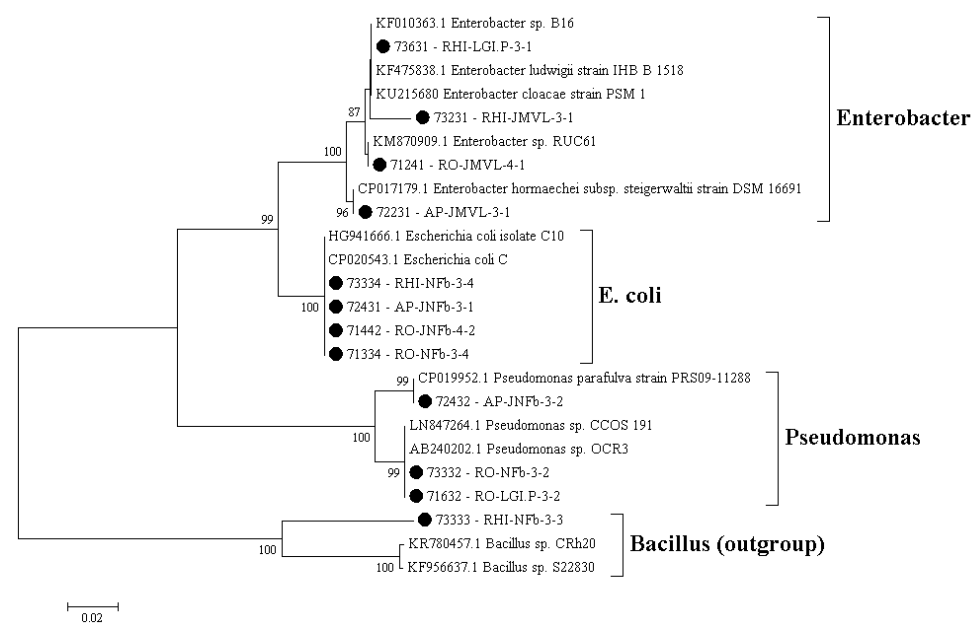

Fig 2. Phylogenetic tree of bacterial isolates obtained from Calophyllum brasiliense Cambess.
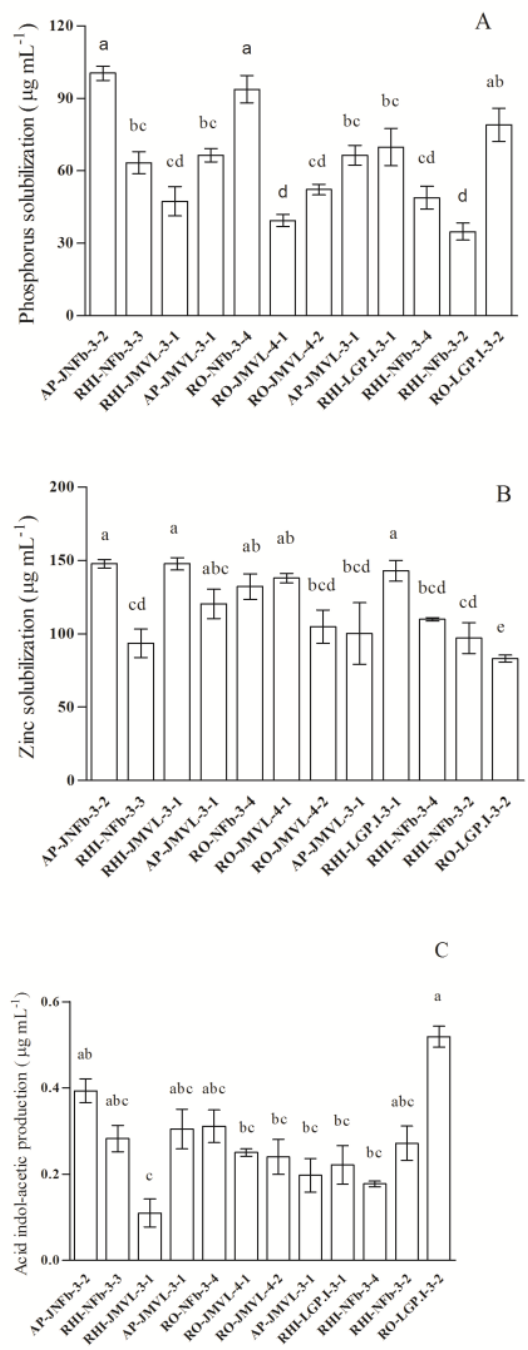

Fig 3. Phosphorus solubilization (A), zinc solubilization (B) and indole acetic acid production (C) by bacterial isolates obtained from Calophyllum brasiliense Cambess. 
RO-JMVL-4-1, RO-JNFb-4-1, RHI-JNFb-3-1, RHI-JNFb-3-2 and RO-LGI-4-1 presented the highest values (halo diameter $>16$ $\mathrm{mm}$, Table 1).

A total of 25 isolates ( $80 \%$ ) presented ability to solubilize zinc, of which 8 had a halo diameter greater than or equal to $13 \mathrm{~mm}$ (Table 1). The isolates AP-JMV-2-1, AP-JMVL-3-1, RO-JNFb-4-3 and RHI-JNFb-3-1 showed the largest halo diameter, with values greater than $16 \mathrm{~mm}$. Contrarily, the isolates RHI-JMV-31, RO-NFb-3-4, RHI-NFb-3-3, AP-JNFb-3-2, RO-JNFb-4-2 and RHI-LGI-2-1 showed no ability to solubilize zinc, as was observed by the absence of a halo.

The soluble phosphorus concentration in the inoculated NBRIP medium ranged between 34.9 and $100.4 \mathrm{~g} \mathrm{~mL}^{-1}$ (Fig. 3A), with the maximum value recorder for the isolate AP-JNFb-3-2. Results from the BLAST search of the 16S rRNA sequences indicated that this isolate is closely related to bacteria belonging to the genus Pseudomonas ( $P$. parafulva CP 019952.1) (Fig. 2). The isolate RO-NFb-3-4, which was statistically similar to AP-JNFb-3-2, presented the second highest value of solubilized phosphorus $\left(93.7 \pm 9.9 \mu \mathrm{g} \mathrm{mL}^{-1}\right.$ ) and was related to the Escherichia coli isolate C10 HG941666.1 and E. coli C CP020543.1. The isolate RO-LGI.P-3-2 showed a solubilized phosphorus concentration of $79.0 \pm 4.3 \mu \mathrm{g} \mathrm{mL}^{-1}$, and was closely related to Pseudomonas sp. CCOS 191 In847264.1 and Pseudomonas sp. OCR3 AB240201.1.

The soluble zinc concentration in the inoculated DYGS medium ranged from 83.0 to $147.8 \mu \mathrm{g} \mathrm{mL}^{-1}$ (Fig. 3B), where the isolates AP-JNFb-3-2 (147.8 $\left.\pm 5.0 \mu \mathrm{g} \mathrm{mL}^{-1}\right)$, RHI-JMVL-3-1 (147.7 \pm 7.3 $\left.\mu \mathrm{g} \mathrm{mL}{ }^{-1}\right)$ and RHI-LGI.P-3-1 (142.9 $\left.\pm 12.4 \mu \mathrm{g} \mathrm{mL} \mathrm{m}^{-1}\right)$ registered the highest values. As shown in subtopic 3.5., the isolate APJNFb-3-2 is closely related to bacteria belonging to the genus Pseudomonas. However, the isolates RHI-JMVL-3-1 and RHILGI.P-3-1were related to genus Enterobacter (E. cloacae strain PSM 1 KU 215680, E. ludwigii strain IHB B 1518 KF 475838.1 or Enterobacter sp. B16 KF 010363.1).

\section{Determination of indole-acetic acidity by bacterial isolates}

The 12 isolates were further tested for IAA production and results are presented in Fig. 3C. The IAA production ranged between $0.11 \pm 0.02 \mu \mathrm{g} \mathrm{mL}^{-1}$ and $0.52 \pm 0.08 \mu \mathrm{g} \mathrm{mL}^{-1}$, with the isolate RO-LGI.P-3-2 presenting the highest value. The $16 \mathrm{~S}$ rRNA sequences indicated close relationship of this isolate with bacteria belonging to the genus Pseudomonas (Pseudomonas sp. CCOS 191 LN 847264.1 or Pseudomonas sp. OCR3 AB240202.1).

\section{Discussion}

Microbial inoculants may induce a series of compounds and biochemical responses that promote plant growth. This study presented for the first time the existence of an interaction between $C$. brasiliensis, an arboreal plant of the Brazilian savanna, with different nitrogen-fixing bacteria species. The predominant colonization of nitrogen-fixing bacteria in the root system has been reported for different plant species (Singh et al.,2011), being the main site of bacterial infection of cavities caused by the disruption of epidermal cells during the emergence of lateral roots and endophytic establishment by colonization of intercellular spaces of the cortical parenchyma (Baldotto et al., 2011). These bacteria, in addition to fixing nitrogen, are able to solubilize nutrients and synthesize phytohormones, and are therefore biological materials with potential for use as promoters of plant growth (Singh et al., 2011).

Among the isolates that could be identified by $16 \mathrm{~S}$ rRNA sequencing, AP-JNFb-3-2 was closely related to the genus Pseudomonas (P. parafulva CP 019952.1) and presented greater ability to solubilize phosphorus in NBRIP medium, with a value of $100.4 \mathrm{\mu g} \mathrm{mL}^{-1}$. This concentration is lower than those observed by Gupta et al. (2012) who reported that bacteria associated with Aloe barbadensis presented phosphorus solubilization from 150 to $340 \mu \mathrm{g} \mathrm{mL}{ }^{-1}$. The nearest species of the isolates obtained by Gupta et al. (2012) were identified as Pseudomonas synxantha, Burkholderia gladioli, Enterobacter hormaechei and Serratia marcenses. Likewise, Awais et al. (2017) isolated phosphorus-solubilizing bacteria from the rhizosphere of sugarcane and rice, and observed that solubilization ranged from 50.07 to $717.99 \mathrm{ppm}$ $\left(\mu \mathrm{g} \mathrm{mL}^{-1}\right)$ in NBRIP and Pikovskaya media.

Brazilian savanna soils are generally acidic and deficient of nutrients (Lopes and Guilherme, 2016), and therefore solubilization of inorganic phosphate ability is of great interest for selection of microorganisms with potential to be explored as $\mathrm{Ml}$ in agriculture. An evaluation of potential phosphate solubilizers of 20 rice root isolates, grown in the Brazilian savanna region, verified that $75 \%$ presented solubilizing ability in Pikovskaya medium, and the 16S rRNA gene sequencing analysis revealed that all evaluated isolates showed high similarity with the Bacillus genus (Braga et al., 2018).

Phosphorus solubilizing activity is determined by the microbial ability to produce and release organic acids, which through their carboxylic groups chelate the cations bound to phosphorus or decrease the $\mathrm{pH}$, converting phosphorus into soluble forms (Gupta et al., 2012; Awais et al., 2017). Chen et al.(2006) used high performance liquid chromatography (HPLC) analysis to detect citric, gluconic, lactic, succinic, propionic acid and three other unknown organic acids produced from the culture of Bacillus, Rhodococcus, Arthobacter, Serratia, Chryseobacterium, Delftia, Gordonia and Phyllombacterium. Shahid et al. (2012) observed that Enterobacter sp. produced gluconic and malic acids, resulting in $43.5 \mathrm{\mu g} \mathrm{mL}^{-1}$ of solubilized phosphorus. Other bacteria belonging to the genera Enterobacter, Arthrobacer, Azotobacter, Bacillus and Serratia are also able to produce different organic acids, resulting in solubilized phosphorus concentrations ranging between 270.2 and $623.6 \mathrm{\mu g} \mathrm{mL}^{-1}$ (Chen et al., 2006; Yi et al., 2008).

However, although the release of the organic acids has been indicated as one of the main factors responsible for phosphorus solubilization, there are also reports which suggest that insoluble phosphorus may be solubilized without any organic acid production (Kim et al., 1997; Chen et al., 2006). Inorganic acids such as chloric acid (Kim et al. 1997), nitric and sulfuric acids (Dugan et al. 1965) produced by chemoautotrophs and the activity of the $\mathrm{H}^{+}$pump, for example, have been reported as possible mechanisms to promote inorganic phosphorus solubilization (Reyes et al., 1999). The present work did not seek to determine the 
mechanisms responsible for solubilization, but only to identify the most promising bacteria. In this sense, the isolates APJNFb-3-2 and RO-LGI.P-3-2, which were identified as belonging to the genus Pseudomonas, presented the greatest potential to act as agents of phosphorus solubilization.

Zinc is a nutrient required by plants as a component of enzymatic reactions, carbohydrate metabolism, auxin synthesis and also plays a vital role in regulation of the gene expression needed for tolerance to environmental stresses (Gontia-Mishra et al., 2017). Zinc deficiency in crops is due to its low solubility rather than low availability in soil (Iqbal et al., 2010). Thus, bacteria acting as solubilization agents applied in MI may aid the plants in assessing this nutrient. A total of 25 isolates from $C$. brasiliensis tissues and the rhizosphere presented ability to solubilize zinc in the qualitative test, of which eight presented halo diameters greater than or equal to $13 \mathrm{~mm}$. This result is similar to that reported by Ramesh et al. (2014) and Mumtaz et al.(2017) in studies involving zinc solubilization by bacteria belonging to the genus Bacillus.

In quantitative measurement, the isolates AP-JNFb-3-2, RHIJMVL-3-1 and RHI-LGP-3-1, closely related to bacteria belonging to the genera Pseudomonas and Enterobacter, presented the greatest solubilization potential with zinc content in the media between 142.9 and $147.8 \mu \mathrm{g} \mathrm{mL}^{-1}$. These values agree with those presented by Khande et al. (2017) who isolated bacteria from the rhizosphere of two soybean cultivars grown in India and obtained values for zinc solubilization ranging from 89.00 to $547.38 \mu \mathrm{g} \mathrm{mL}$. These isolates obtained by Khande et al.(2017) were identified as Bacillus cereus, $B$. anthracis, $B$. thuringiensis, B. tequilensis and $B$. subtilis subsp. Inaquosorum. Previous reports demonstrate the ability of bacteria from the genus Pseudomonas to solubilize zinc from various insoluble zinc compounds ( $\mathrm{Di}$ Simine and Sayer, 1998; Gontia-Mishra et al., 2017).

The creation of acidic conditions in liquid media by bacteria isolates from the production of different organic acids has been also reported, similar to phosphorus, as the major cause of zinc solubilization (Saravanan et al., 2003; Ramesh et al., 2014). Di Simine et al.(1998) observed that gluconic acid and 2 keto gluconic acids produced by Pseudomonas fluorescens aided the solubilization of zinc salts and Gontia-Mishra et al.(2017) showed a positive correlation between solubilization of zinc by Pseudomonas aeruginosa and $\mathrm{pH}$ media reduction. Production of organic acids by the isolates obtained from $C$. brasiliensis sharply reduced the $\mathrm{pH}$ in the media (data not shown), allowing for zinc solubilization.

The 12 isolates identified by PCR analysis produced IAA at concentrations between 0.11 and $0.52 \mu \mathrm{g} \mathrm{mL}^{-1}$. This range is below that observed by Posada et al.(2016) who reported concentrations produced by bacteria from the rhizosphere of banana between 1.9 and $60.0 \mu \mathrm{g} \mathrm{mL}^{-1}$. Mumtaz et al.(2017) also reported higher IAA production by bacterial endophyte isolates from rice seeds (between 11.5 to $38.8 \mu \mathrm{g} \mathrm{mL}^{-1}$ ) and by Bacillus spp (between 2.6 to $15.8 \mu \mathrm{g} \mathrm{mL}^{-1}$ ), respectively. On other hand, Tsavkelova et al.(2005a, 2007b) showed that the quantities of IAA secreted in the liquid culture by bacteria isolated from tropical orchids varied from 0.5 to $92.9 \mu \mathrm{g} \mathrm{mL}^{-1}$. Thus, it is possible to conclude that IAA produced by bacteria varies greatly according to the species strain. The most promising isolate observed in the present work was RO-LGI.P3-2 and the 16S rRNA sequences indicated a close relationship with bacteria from the genus Pseudomonas (Pseudomonas $s p$. CCOS 191 LN 847264.1 or Pseudomonas sp. OCR3 AB240202.1).

\section{Materials and methods}

\section{Isolation and quantification of bacteria}

Aerial parts (leaves and branches) from different $C$. brasiliensis plants were collected in adult specimens (approximately 10 years) together with their rhizospheric soil and fine roots in Brasília, Federal District of Brazil. The material was collected using sterilized plastic bags and immediately sent to the laboratory for isolation of nitrogen-fixing bacteria according the procedure described by (Döbereiner et al., 1995). The material was surface-disinfected using $70 \%(\mathrm{v} / \mathrm{v})$ ethanol for 1 min by shaking, followed by adding $3 \%(\mathrm{v} / \mathrm{v})$ sodium hypochlorite and slowly shaking for $15 \mathrm{~min}$, and then washed four times with sterile distilled water. Samples of $1.0 \mathrm{~g}$ of the surface-disinfected fine roots and aerial parts were crushed separately with a mortar in $9.0 \mathrm{~mL}$ of sterile saline solution $\left(\mathrm{NaCl}, 0.85 \mathrm{~g} \mathrm{~L}^{-1}\right)$. In order to isolate the bacteria present in the rhizosphere, $1.0 \mathrm{~g}$ of the soil adhered to the roots was also shaken in the same sterile saline solution for $5 \mathrm{~min}$ at the same soil: solution ratio. From both diluted solutions $\left(10^{-1}\right)$, serial dilutions from $10^{-2}$ to $10^{-6}$. were obtained. Thus, $0.1 \mathrm{~mL}$ aliquots from each diluted solution were placed in vials containing 5.0 $\mathrm{mL}$ of six $\mathrm{N}$-free semisolid specific media: JNFb, NFb, LGI, LGI-P, JMV or JMVL. The material was then incubated at $30{ }^{\circ} \mathrm{C}$ for 7 days. After this, the bacterial population was determined by the most probable number technique (MPN) using three replications and expressed as the log of the cell number $\mathrm{g}^{-1}$ of tested material after growth on the different media.

Vials from the lowest serial dilutions that showed a fine subsurface pellicle were used for isolation of pure colonies which were then transferred to fresh semisolid JNFb, NFb, LGI, LGI-P, JMV or JMVL media, followed by several purification steps (Döbereiner et al., 1995). New growth was then streaked on agar plates of the same media and incubated at $30^{\circ} \mathrm{C}$ for 7 days. Subsequently, isolated colonies were selected according to their similar morphologic characteristics and transferred by streaking to a new plate with the same culture medium for purification.

\section{Morphological characterization and gram coloring evaluation}

Isolates were subcultured on DYGS semi-solid and specific

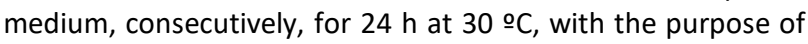
evaluating the morphological characteristics of both colonies and bacterial cells according to Lozada et al. (2018). An isolate code was thus assigned to identify the bacteria as follows: the origin of the material used (Root = RO; Aerial part = AP; Rhizosphere $=\mathrm{RHI}$ ); the culture medium used (JMV, JMVL, NFb, JNFb, LGI and LGI.P); the dilution used $\left(1=10^{-2} ; 2=10^{-3} ; 3=\right.$ $10^{-4} ; 4=10^{-5} ; 5=10^{-6}$ ) and a number to differentiate bacterial strains isolated from the same Petri dish. 


\section{Genomic DNA isolation, PCR amplification and 16S rRNA sequence analysis}

Bacterial isolates were identified based on partial sequencing of the $16 \mathrm{~S}$ rRNA gene. In summary, genomic DNA was isolated in duplicate using a DNA \& RNA Purification Bacterial Genomic Miniprep Kit (Sigma Aldrich) and then pooled. Universal PCR primers for the bacteria 16S rDNA genes $27 \mathrm{f}\left(\left(5^{\prime}\right.\right.$ AGAGTTTGATCCTGGCTCAG-3')Lane,1991) and 1492r ((5'GGTTACCTTGTTACGACTT-3')Lane,1991) were used to amplify a PCR product of the expected size (1465 bp). The microliter reaction mixtures utilized $0.6 \mu \mathrm{M}$ each of the primer, $\sim 5 \mathrm{ng}$ of template DNA, 1× PCR reaction buffer and $2.5 \mathrm{U}$ of Pfu DNA Polymerase (MBI. Fermentas, USA). The amplification program consisted of an initial denaturation step at $96{ }^{\circ} \mathrm{C}$ for $5 \mathrm{~min}$ followed by 25 cycles, where 1 cycle consisted of $96^{\circ} \mathrm{C}$ for $30 \mathrm{~s}$ (denaturation), $55^{\circ} \mathrm{C}$ for $30 \mathrm{~s}$ (annealing), $72{ }^{\circ} \mathrm{C}$ for $1 \mathrm{~min}$ and $30 \mathrm{~s}$ (extension), and a final extension at $72{ }^{\circ} \mathrm{C}$ for $5 \mathrm{~min}$. PCR products were visualized on agarose gels ( $2 \%$ in TBE buffer) containing ethidium bromide and purified with a GFX ${ }^{\mathrm{TM}} 96 \mathrm{PCR}$ Purif kit (GE Healthcare), to be sequenced using an Applied Biosystems Sequencer ( $A B I$ 3730xI DNA Analyzer). The sequences were deposited in the National Center for Biotechnology Information (NCBI bank database, www.ncbi.nlm.nih.gov) with accession numbers from $\mathrm{MH} 304298$ to MH304309.

\section{Phylogenetic analysis}

Sequences were aligned using the Genius MAFFT plugin (version 8.1.1) with default settings, and phylogenetic trees were constructed using the Neighborg-Joining method based on Kimura's two-parameter genetic distances matrix with 1,000 bootstrap replicates $(n=1000)$ in the MEGA 6.0 package (Molecular Evolutionary Genetics Analysis) (Tamura, et al., 2013).

\section{Qualitative and quantitative phosphorus and zinc solubilizing analysis}

Isolates were characterized by their ability to solubilize phosphate and zinc based on the formation of a visible dissolution halo on solid medium. For phosphorus, the isolates were grown in DYGS liquid medium for $24 \mathrm{~h}$, at $30{ }^{\circ} \mathrm{C}$ and 120 rpm. Aliquots of $20 \mu \mathrm{L}$ of the bacterial suspensions were incubated at $30{ }^{\circ} \mathrm{C}$, for 7 days, in Petri dishes containing solid culture medium prepared at $\mathrm{pH} 7.0$ using: $10.0 \mathrm{~g}$ of glucose, $5.0 \mathrm{~g}$ of ammonium chloride $\left(\mathrm{NH}_{4} \mathrm{Cl}\right), 1.0 \mathrm{~g}$ of sodium chloride $(\mathrm{NaCl}), \quad 1.0 \mathrm{~g}$ of magnesium sulfate heptahydrate $\left(\mathrm{MgSO}_{4} .7 \mathrm{H}_{2} \mathrm{O}\right), 1.0 \mathrm{~g}$ of calcium phosphate $\left(\mathrm{Ca}_{5}\left(\mathrm{PO}_{4}\right)_{3} \mathrm{OH}\right), 15 \mathrm{~g}$ of agar and $1 \mathrm{~L}$ of distilled water (Verma et al.,2001). For zinc, the isolated bacteria were grown in the same DYGS liquid medium at the same conditions and aliquots of $20 \mu \mathrm{L}$ of the bacterial suspensions were incubated at $30^{\circ} \mathrm{C}$, for 7 days, in Petri dishes containing solid culture medium prepared at $\mathrm{pH}$ 7.0 using: $10.0 \mathrm{~g}$ of glucose, $1.0 \mathrm{~g}$ of ammonium sulfate $\left(\left(\mathrm{NH}_{4}\right)_{2} \mathrm{SO}_{4}\right), 0.2 \mathrm{~g}$ of potassium chloride $(\mathrm{KCl}), 0.1 \mathrm{~g}$ of dipotassium hydrogen phosphate $\left(\mathrm{K}_{2} \mathrm{HPO}_{4}\right), 0.2 \mathrm{~g}$ of magnesium sulfate heptahydrate $\left(\mathrm{MgSO}_{4} .7 \mathrm{H}_{2} \mathrm{O}\right), 1.0 \mathrm{~g}$ of zinc oxide ( $\mathrm{ZnO}), 15 \mathrm{~g}$ of agar and $1 \mathrm{~L}$ of distilled water (Saravanan et al., 2003).

The halo diameter for both tests was measured using a digital caliper and calculated using the mathematical formula: halo diameter $(\mathrm{mm})=$ total diameter - colony diameter. This difference was used to qualitatively determine, with three replicates, the ability of the isolates to solubilize phosphorus and zinc.

The phosphorus solubilization potential of the isolates identified based on the sequence analysis was evaluated using Falcon tubes containing $10 \mathrm{~mL}$ of NBRIP medium. The NBRIP medium was prepared at $\mathrm{pH} 7.0$ using: $10.0 \mathrm{~g}$ of glucose, $5.0 \mathrm{~g}$ of calcium phosphate $\left(\mathrm{Ca}_{5}\left(\mathrm{PO}_{4}\right)_{3} \mathrm{OH}\right), 5.0 \mathrm{~g}$ of magnesium chloride $\left(\mathrm{MgCl}_{2} \cdot 6 \mathrm{H}_{2} \mathrm{O}\right), 0.25 \mathrm{~g}$ of magnesium sulfate heptahydrate $\left(\mathrm{MgSO}_{4} .7 \mathrm{H}_{2} \mathrm{O}\right), 0.2 \mathrm{~g}$ of potassium chloride $(\mathrm{KCl})$, $0.1 \mathrm{~g}$ of $\left(\mathrm{NH}_{4}\right)_{2} \mathrm{SO}_{4}$ and $1 \mathrm{~L}$ of distilled water (Nautiyal, 1999). $100 \mu \mathrm{L}$ of inoculum containing $10^{8} \mathrm{CFU} \mathrm{\textrm {mL } ^ { - 1 }}$ of each bacteria

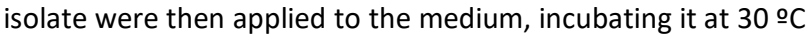
for 5 days. An uninoculated control was also maintained under the same conditions. The tubes were centrifuged at 10,000 rpm for $10 \mathrm{~min}$ and phosphorus in the supernatant was estimated by the molybdo-phosphoric blue color method using a spectrometer at $885 \mathrm{~nm}$ (UV-vis 8454, Agilent Technologies, Santa Clara, USA).

Zinc solubilization potential of the isolates was assessed using Falcon tubes containing $10 \mathrm{~mL}$ of liquid DYGS medium inoculated individually with each isolate obtained $(100 \mu \mathrm{L}$ of

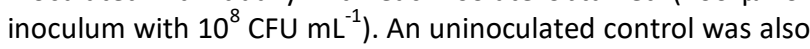
maintained under the same conditions. The liquid DYGS medium was prepared at $\mathrm{pH} 7.0$ using: $10.0 \mathrm{~g}$ of glucose, $0.2 \mathrm{~g}$ of potassium chloride $(\mathrm{KCl}), 0.1 \mathrm{~g}$ of $\left(\mathrm{NH}_{4}\right)_{2} \mathrm{SO}_{4}, 0.2 \mathrm{~g}$ of magnesium sulfate heptahydrate $\left(\mathrm{MgSO}_{4} \cdot 7 \mathrm{H}_{2} \mathrm{O}\right), 0.1 \mathrm{~g}$ of dipotassium phosphate $\left(\mathrm{K}_{2} \mathrm{HPO}_{4}\right), 1.0 \mathrm{~g}$ of zinc oxide $(\mathrm{ZnO})$ and $1 \mathrm{~L}$ of distilled water, and was incubated at 30 으 for 5 days. Subsequently, the tubes were centrifuged at $10,000 \mathrm{rpm}$ for 10 min and zinc in the supernatant was estimated by microwave plasma-atomic emission spectroscopy (MP-AES-4200, Agilent Technologies, Santa Clara, USA).

\section{Determination of indole acetic acid}

Isolates were tested for their ability to produce indole acetic acid (IAA) as assayed by the colorimetric method using ferric chloride-sulfuric acid (IIImer and Schinner, 1995). For this, 1.0 $\mathrm{mL}$ of the previously centrifuged NBRIP medium (topic 2.5) was inoculated in flasks containing $2.0 \mathrm{~mL}$ of Salkowski's reagent prepared using: $1.2 \mathrm{~g}$ of iron trichloride $\left(\mathrm{FeCl}_{3}\right), 42.1 \mathrm{~mL}$ of sulfuric acid $\left(\mathrm{H}_{2} \mathrm{SO}_{4}\right)$ and $57.89 \mathrm{~mL}$ of distilled water. This was maintained at room temperature in the dark for $30 \mathrm{~min}$ and then the development of pink color was measured in the supernatant using a spectrophotometer operating at $535 \mathrm{~nm}$ (UV-vis 8454, Agilent Technologies, Santa Clara, USA). The absorbance was correlated with a standard curve produced using solutions containing synthetic IAA. 


\section{Statistical analysis}

The quantitative results (MPN, phosphorus solubilization, zinc solubilization and IAA production) were evaluated by analysis of variance (ANOVA) and the means were compared using the Tukey's test at $p<0.05$. Qualitative data (morphological and gram nature characterization, phosphorus and zinc solubilizing ability, genomic DNA isolation, PCR amplification and 16S rRNA sequence and phylogenetic analysis) were analyzed descriptively. For each test triplicate samples were taken, except for the genomic and phylogenetic analysis.

\section{Conclusion}

The isolate AP-JNFb-3-2, obtained from the aerial part of the plants and identified as a bacterium belonging to the genus Pseudomonas, was the most promising phosphorus solubilizing bacteria. Isolates AP-JNFb-3-2 and RHI-JMVL-3-1 presented the highest values for zinc solubilization. These bacteria were associated with the genera Pseudomonas and Enterobacter. The isolate RO-LGI.P-3-2, belonging to the genus Pseudomonas, presented the highest value for IAA production. These results obtained in the present work showed the presence of a large diversity of bacteria associated with $C$. brasiliensis, which may be explored for use in $\mathrm{Ml}$ to aid the plants in obtaining nutrients from poor soils of the Brazilian savanna and act as growth regulators for the plants.

\section{Acknowledgments}

This research was supported by the Ministry of Science and Technology of Brazil (CNPq, no 454797/2014-6). We also thank the Coordination for the Improvement of Higher Education Personnel (Capes) and foundation of the Ministry of Education (MEC) for the support provided.

\section{References}

Awais M, Tariq M, Ali A, Ali Q, Khan A, Tabassum B, Nasir IA, Husnain $T$ (2017) Isolation, characterization and interrelationship of phosphate solubilizing bacteria from the rhizosphere of sugarcane and rice. Biocatal Agric Biotechnol. 11:312-321.

Baldotto LEB, Olivares FL, Bressan-Smith R (2011) Structural interaction between gfp-labeled diazotrophic endophytic bacterium (Herbaspirillum seropedicae) ram10 and pineapple plantlets 'Vitória'. Braz J Microbiol. 42:114-125.

Braga LF, Oliveira FA, Couto EAP, Santos KFDN, Ferreira EPB, Martin-Dodonet CCG (2018) Polyphasic characterization of bactéria obtained from upland rice cultivated in cerrado soil. Braz J Microbiol. 49:20-28.

Chen YO, Rekha PD, Arun AB, Shen FT, Lai WA, Young CC (2006) Phosphate solubilizing bacteria from subtropical soil and their tricalcium phosphate solubilizing abilities. Appl Soil Ecol. 34: 33-41.

Di Simine CDD, Sayer JA, Gadd GM (1998) Solubilization of zinc phosphate by a strain of Pseudomonas fluorescens isolated from a forest soil. Biol Fert Soils. 25:87-94.
Döbereiner J, Baldani JI, Baldani VLD (1995) Como isolar e identificar bactérias diazotróficas de plantas não leguminosas. Brasília: Embrapa, SPI.; Itaguaí: Embrapa, CNPAB. 60p.

Du Jardin (2015) P. Plant biostimulants: definition, concept, main categories and regulation. Sci Hortic-England.196;3-14.

Dugan P, Lungren DG (1965) Energy supply for the chemoautotroph Ferrobacillus ferroxidans. J Bacteriol. 89:825-834.

Gontia-Mishra I, Sapre S, Tiwari S (2017) Zinc solubilizing bacteria from the rhizosphere of rice as prospective modulator of zinc biofortification in rice. Rhizosphere. 3:185190.

Groppa MD, Benavides MP, Zawoznik MS (2012) Root hydraulic conductance, aquaporins and plant growth promoting microorganisms: a revision. Appl Soil Ecol. 61:247-254.

Gupta M, Kiran S, Gulati A, Singh B, Tewari R (2012) Isolation and identification of phosphate solubilizing bacteria able to enhance the growth and aloin-a biosynthesis of Aloe barbadensis Miller. Microbiol Res. 167:358-363.

Illmer P, Schinner F (1995) Solubilization of inorganic calcium phosphates solubilization mechanisms. Soil Biol Biochem. 27:257-263.

Iqbal U, Jamil N, Ali I, Hasnain S (2010) Effect of zincphosphate-solubilizing bacterial isolates on growth of Vigna radiate. Ann Microbiol. 60:243-248.

Khande R, Sharma SK, Ramesh A, Sharma MP (2017) Zinc solubilizating Bacillus strains that modulate growth, yield and zinc biofortification of soyben and wheat. Rhizosphere. 4:126-138.

Kim KY, Jordan D, Krishan HB (1997) Rahnella aquatilis, bacterium isolated from soybean rhizosphere hydroxyapatite. FEMS Microbiol Lett. 153:273-277.

Lane Dj (1991) 16S/23S rRNA sequencing. In: stackebrandt e, goodfellow $\mathrm{m}$, editors. Nucleic acid techniques in bacterial systematics. New York, NY: John Wiley and Sons. 115-75.

Lopes AS, Guilherme LRG (2016) A career perspective on soil management in the cerrado region of Brazil. Adv Agron. 137:1-72.

Lozada JAR, Silveira KC, Silva LJ, Baldotto MA, Baldotto LEB (2018) Selection of diazotrophic bacteria isolated from wastewater treatment plant sludge at a poultry slaughterhouse for their effect on maize plants. Rev Ceres. 65:85-92.

Mumtaz M Z, Ahmad M, Jamil M, Hussain T (2017) Zinc solubilizing Bacillus sp. potential candidates for biofortification in maize. Microbiol Res. 202:51-60.

Nautiyal CS (1999) An efficient microbiological growth medium for screening phosphate solubilizing microorganisms. FEMS Microbiol Lett. 170:265-270.

Posada LF, Ramírez M, Ochoa-Gómez N, Cuellar-Gaviria TZ, Argel LE, Ramirez CA, Villegas-Escobar V (2016) Bioprospecting of aerobic endospore-forming bacteria with biotechnological potential for growth promotion of banana plants. Sci Hortic-England. 212:81-90.

Rada N (2013) Assessing Brazil's cerrado agricultural miracle. Food Policy. 38:146-155. 
Ramesh A, Sharma SK, Sharma MP, Yadav N, Joshi OP (2014) Inoculation of zinc solubilizing Bacillus aryabhattai strains for improved growth, mobilization and biofortification of zinc in soybean and wheat cultivated in vertisols of central India. Appl Soil Ecol. 73:87-96.

Reyes I, Bernier L, Simard R, Antoun H (1999) Effect of nitrogen source on solubilziation of different inorganic phosphates by bacterial strain of Penicillium rugulosum and two (uv) induced mutants. FEMS Microbiol Ecol. 28:281-290.

Saravanan VS, Subramanian R, Raj A (2003) Assessing in vitro solubilization potential of different zinc solubilizing bacterial (zsb) isolates. Braz J Microbiol. 34:121-125.

Sarma BK, Yadav SK, Singh S, Singh HB (2015) Microbial consortium-mediated plant defense against phytopathogens: readdressing for enhancing efficacy. Soil Biol Biochem. 87:25-33.

Shahid M, Hameed S, Imran A, Ali S, van Elsas JD (2012) Root colonization and growth promotion of sunflower Helianthus annuus L. by phosphate solubilizing Enterobacter sp.. Fs-11. World J Microb Biot. 28:2749-2758.

Singh JS, Pandey VC, Singh DP (2011) Efficient soil microorganisms: a new dimension for sustainable agriculture and environmental development. Agric Ecosyst Environ. 140:339-353.
Tamura K, Stecher G, Peterson D, Filipski A, Kumar S (2013) Mega6: molecular evolutionary genetics analysis version 6.0. Mol Biol Evol. 30:2725-2729.

Tsavkelova EA, Cherdynstseva TA, Botina SG, Netrusov AI (2007) Bacteria associated with orchid roots and microbial production of auxin. Microbiol Res. 162:69-76.

Tsavkelova EA, Cherdynstseva TA, Netrusov Al (2005) Auxin production by bacteria associated with orchid roots. Microbiology. 74:46-53. doi.org/10.1007/s11021-0050027-6

Verma SC, Ladha JK, Tripathi AK (2001) Evaluation of plant growth promoting and colonization ability of endophytic diazotrophs from deep water rice. J Biotechnol. 91:127-141.

Yi Y, Huang W, Ge Y (2008) Exo-polusaccharide: a novel important factor in the microbial dissolution of tricalcium phosphate. World J Microb Biot. 24:1059-1065. 